\title{
Extraction of $\beta$-glucan from Saccharomyces cerevisiae: Comparison of different extraction methods and in vivo assessment of immunomodulatory effect in mice
}

\author{
Noppawat PENGKUMSRI ${ }^{1}$, Bhagavathi Sundaram SIVAMARUTHI ${ }^{1}$, Sasithorn SIRILUN ${ }^{1}$, Sartjin PEERAJAN ${ }^{2}$, \\ Periyanaina KESIKA ${ }^{1}$, Khontaros CHAIYASUT $^{2}$, Chaiyavat CHAIYASUT ${ }^{1 *}$
}

\begin{abstract}
Beta-glucan (BG) is a conserved cell wall components of bacteria, fungi, and yeast. BG is an immunomodulator and stimulates the host immune system. This study was performed to screen Saccharomyces cerevisiae strain with high BG, extraction of BG using different chemical extraction methods, composition analysis of BG, and evaluation of the immunomodulatory effect of high-quality BG using mice model. Ten yeast strains were screened for high BG content using total glucan extraction kit and were subjected to FT-IR analysis. The kit based extraction revealed that HII31 showed a high content of total glucan and BG. HII31 cells were subjected to four different acid/base extractions, which indicated that combination of a strong base $(\mathrm{NaOH})$ and weak acid $\left(\mathrm{CH}_{3} \mathrm{COOH}\right)$ extraction recovered high $\mathrm{BG}$ and a high ratio of polysaccharide, protein, and lipid. Further, the immunomodulatory effect of the selected BG was evaluated using mice, which suggested that low dose of HII31-BG induces the expression of selected pro-inflammatory (IL-17, IFN- $\gamma$ ) and anti-inflammatory cytokine (IL-10) significantly, whereas relatively high dose was required to alter the IL- 6 and TGF- $\beta$ expression. Overall, the present study revealed that BG extracted from HII 31 cells alters the expression of studied cytokines, which can be used as a potent immunomodulator in pharmaceutical products.
\end{abstract}

Keywords: beta-glucan; Saccharomyces cerevisiae; immunomodulation; FTIR; cytokines.

Practical Application: Identification of optimum extraction procedure for $\beta$-glucan (BG) from S. cerevisiae HII31 and revealed that BG can be used as a potent immune modulator in pharmaceutical products.

\section{Introduction}

Beta-glucan (BG) is one of the most abundant forms of polysaccharides with the heterogeneous groups of glucose polymers connected by a $1 \rightarrow 3$ linear $\beta$-glycosidic chain hub. BG is unique depending on length and structure of the branches. Even though BG has highly variable branches, $1 \rightarrow 4$ or $1 \rightarrow 6$ glycosidic chains are the major branching group (Chan et al., 2009). BG is present everywhere from bacteria to plants with different conformational complexity from single helix to the triple helix, or random coils. BG of yeast cell wall consists of $1 \rightarrow 3 \beta$-linked glucopyranosyl residues with small numbers of $1 \rightarrow 6 \beta$-linked branches (Volman et al., 2008). In contrast, the plant (oat and barley) cell walls contains unbranched BG with $1 \rightarrow 3$ and $1 \rightarrow 4 \beta$-linkage, whereas BG from bacterial origin consist of unbranched $1 \rightarrow 3 \beta$-linkages (Brown \& Gordon, 2003; Brown et al., 2003).

BG has various functional properties that can be utilized in food industries for the preparation of soups, sauces, beverages, and other food products where BG act as stabilizing, thickening agents, and emulsifier (Dawkins \& Nnanna, 1995; Burkus \& Temelli, 2000; Sánchez-Madrigal et al., 2015). BG is also known for several beneficial effects on various diseases and disorders such as colorectal cancer (Dongowski et al., 2002), prevention of coronary heart disease (Wang et al., 2002), blood glucose levels and insulin resistance (Hallfrisch et al., 2003; Hlebowicz et al.,
2008), serum cholesterol levels, and gut microflora (Tungland, 2003). BG is a potent immunomodulator (Volman et al., 2008).

The effects of the BG on the immune system are evidently dependent on the structural intricacy of them, and it has been revealed that more complexities are linked with added potent immunomodulatory effect (Chan et al., 2009). The host immune receptors will recognize the carbohydrate moiety of BG present in the invading fungal pathogens and elucidate the defensive response (Brown \& Gordon, 2005). Chan et al. (2009) have reviewed the involvement of BG in both innate and adaptive immune responses.

BG occupies the large part of yeast biomass and is vital for cell functions (Bacic et al., 2009). BG of Saccharomyces cerevisiae can induce the production of TNF- $\alpha$ and also activates the mononuclear cells, and neutrophils in vitro (Olson et al., 1996). BG can trigger the host immune cells and cytotoxicity in cancer cells (Chan et al., 2009; Vetvicka, 2011). Several extraction techniques are there to recover the potent $\mathrm{BG}$ from microbial and plant sources, but the choice of suitable extraction method plays a vital role that will affect the structure, quality, and functionality of the BG (Ahmad et al., 2012).

Extraction of BG from S. cerevisiae generally consists of two major steps such as yeast cell lysis (separation of cell wall 
from cytoplasm) and BG extraction (extraction from insoluble cell wall) (Javmen et al., 2012). Several studies reported about chemical ( $\mathrm{NaOH}, \mathrm{HCl}$, acetic acid, citric acid) (Lee et al., 2001; Hunter et al., 2002; Pelizon et al., 2005), physical (sonication, high pressure) (Boonraeng et al., 2000; Shokri et al., 2008; Wenger et al., 2008) and enzymatic (lytic enzymes) lysis of yeast cells (Ferrer, 2006).

The objectives of the current study are to achieve the selection of S. cerevisiae strain with a high content of BG, extraction of BG by different chemical extraction method, analysis of the composition of extracted BG, and evaluation of the immunomodulatory effect of extracted BG using mice model.

\section{Materials and methods}

\subsection{S. cerevisiae strains}

The strains of Saccharomyces cerevisiae used in this study include HII31, which was obtained from the Health Innovation Institute, Chiang Mai, Thailand and the 9 S. cerevisiae representative strains (TISTR5003, TISTR5024, TISTR5051, TISTR5059, TISTR5191, TISTR5197, TISTR5278, TISTR5328, and TISTR5623) were obtained from the Thailand Institute of Scientific and Technological Research (TISTR).

\subsection{Growth medium preparation and glucan determination}

S. cerevisiae strains were grown in Yeast Extract-Glucose broth (YG broth) (15 g/L glucose, $5.2 \mathrm{~g} / \mathrm{L} \mathrm{K}_{2} \mathrm{HPO}_{4}, 3.18 \mathrm{~g} / \mathrm{L}$ $\mathrm{KH}_{2} \mathrm{PO}_{4}, 0.12 \mathrm{~g} / \mathrm{L} \mathrm{MgSO}_{4}, 0.5 \mathrm{~g} / \mathrm{L}$ Yeast extract, and $0.54 \mathrm{~g} / \mathrm{L}$ $\left.\mathrm{NH}_{4} \mathrm{Cl}\right)$. The yeast cells $(10 \% \mathrm{w} / \mathrm{v})$ were inoculated in $1.0 \mathrm{~L}$ of YG broth in the bioreactor and incubated with the agitation of $200 \mathrm{rpm}$ at $30^{\circ} \mathrm{C}$ with $0.8 \mathrm{vvm}\left(\mathrm{dm}^{3} / \mathrm{min}\right)$ aeration for $48 \mathrm{~h} /$ round. The yeast cells were collected via centrifugation at 7,500 rpm for $10 \mathrm{~min}$ at $4{ }^{\circ} \mathrm{C}$. The $\beta$-glucan was determined by yeast glucan assay kit (Megazyme, Ireland). Briefly, 1,3- $\beta$ - d-glucans, $1,6-\beta$ - $d$-glucans and $\alpha$-glucans are solubilized in concentrated $(37 \% ; 10 \mathrm{~N})$ hydrochloric acid and then hydrolyzed by $1.3 \mathrm{~N}$ $\mathrm{HCl}$ at $100^{\circ} \mathrm{C}$ for $2 \mathrm{~h}$. Hydrolysis to d-glucose is completed by incubating with a mixture of highly purified exo- $1,3-\beta$-glucanase and $\beta$-glucosidase. The released glucose was determined at $510 \mathrm{~nm}$. The concentration of total glucan, BG, and AG was calculated as per the manufacturer's instructions.

\subsection{Autolysis of yeast cell}

The selected high BG containing strain was subjected to autolysis. Briefly, the suspension of $15 \% \mathrm{w} / \mathrm{v}$ of yeast cells in distillation water $\mathrm{pH} 5.0(\mathrm{pH}$ adjusted using $1.0 \mathrm{M} \mathrm{HCl})$ were incubated at $50^{\circ} \mathrm{C}$ for $48 \mathrm{~h}$ with shaking at $120 \mathrm{rpm}$. The autolysis reaction was terminated by incubating at $80^{\circ} \mathrm{C}$ for $15 \mathrm{~min}$ in a water bath. After incubation yeast cells were collected by centrifugation at $4{ }^{\circ} \mathrm{C}$ for $10 \mathrm{~min}$ at $5,000 \mathrm{rpm}$. The pellets were dried at $60^{\circ} \mathrm{C}$ and stored at $4{ }^{\circ} \mathrm{C}$ until extraction.

\subsection{Manual extraction of $\beta$-glucan}

The extraction of $\beta$-glucan was done by using the following combination of acids and bases:
1. $\mathrm{NaOH} / \mathrm{HCl}$ extraction (E1); 2. $\mathrm{NaOH} / \mathrm{CH}_{3} \mathrm{COOH}$ extraction (E2); 3. NaOH/ NaClO extraction (E3); $4 . \mathrm{NaOH}$ and $\mathrm{NaClO} / \mathrm{DMSO}$ extraction (E4).

In detail, the autolyzed yeast cells were mixed with 5 fold of $1.0 \mathrm{M} \mathrm{NaOH}$ (extraction no. E1, E2) and incubated at $80{ }^{\circ} \mathrm{C}$ in stirrer for $2 \mathrm{~h}$. Then, the cell pellet was collected by centrifugation at $6,000 \times g$ for $25 \mathrm{~min}$ at $4{ }^{\circ} \mathrm{C}$ and suspended in 3 fold of distillation water. After thorough mixing, cells were centrifuged at $6,000 \times g$ for $25 \mathrm{~min}$ at $4{ }^{\circ} \mathrm{C}$. After that, the cell pellet was dissolved in 5 fold of $1.0 \mathrm{HCl}$ (extraction no. E1) or $1.0 \mathrm{CH}_{3} \mathrm{COOH}$ (extraction no. E2) and incubated at $80^{\circ} \mathrm{C}$ in stirrer for $2 \mathrm{~h}$. Then the pellet was collected by centrifugation at $6,000 \times g$ for $25 \mathrm{~min}$ at $4{ }^{\circ} \mathrm{C}$. The obtained pellet was washed with water 3 times and dried in hot air oven at $60^{\circ} \mathrm{C}$.

In the case of extraction-E3, yeast cells were mixed with $1.0 \mathrm{M}$ $\mathrm{NaOH}$ (5 fold) and $\mathrm{NaClO}$ (at $2 \%$ of the final concentration) and incubated at $80{ }^{\circ} \mathrm{C}$ in stirrer for $2 \mathrm{~h}$. Then cell pellet was collected by centrifugation at $6,000 \times g$ for $25 \mathrm{~min}$ at $4{ }^{\circ} \mathrm{C}$, and the pellet was washed with distilled water and dried. In the case of extraction- E4, yeast cells were mixed with $1.0 \mathrm{M} \mathrm{NaOH}$ ( 5 fold) and $\mathrm{NaClO}$ (at $2 \%$ of the final concentration) and incubated at $80{ }^{\circ} \mathrm{C}$ in stirrer for $2 \mathrm{~h}$. Then cell pellet was collected by centrifugation at $6,000 \times g$ for $25 \mathrm{~min}$ at $4{ }^{\circ} \mathrm{C}$, and the pellet was washed with distilled water. The pellet was dissolved in 5 fold of DMSO and incubated at $80^{\circ} \mathrm{C}$ in stirrer for $2 \mathrm{~h}$. Then, the pellet was collected by centrifugation and dried. The obtained glucan pellets were stored at $4{ }^{\circ} \mathrm{C}$ until analysis.

\subsection{FT-IR spectroscopic analysis}

Glucan extracted from different methods were analyzed by FTIR spectrometer (Nicolet Nexus 470FT-IR instrument, USA) by following the standard $\mathrm{KBr}$ method (Sivamaruthi et al., 2015; Kesika et al., 2015). An average of 32 scans was computed with a spectral range of 400 to $4,000 \mathrm{~cm}^{-1}$ at $4 \mathrm{~cm}^{-1}$ resolution. All measurements were acquired in duplicate normalization. Spectra were pre-processed (baseline correction, normalization, and second derivative) with OMNIC 32 software before analysis. The Origin Pro 8.0 software was used to calculate the area of curve-fitting.

\subsection{In vivo immunomodulatory effect}

Approximately twenty-four BALB/cMlac mice (6 weeks old) were randomly divided into the following 4 groups, Group: 1 - Control ( $n=6)$; Group: 2, 3, 4 - Experimental group (supplemented with 100 or 150 or $200 \mathrm{mg}$ of air-dried BG/kg of body weight, respectively) ( $n=6 /$ each group). All the mice were reconditioned for 7 days and were maintained for 7 days with daily oral administration of specified concentration of air-dried $\beta$-glucan. After 7 days of $\beta$-glucan supplementation, mice were sacrificed, and level of representative cytokines such as IL-6, IL-10, IL-17, IFN- $\gamma$, and TGF- $\beta$ was determined in serum by ELISA (R\&D system, USA). The animal experiments were conducted as per the regulations and permission of Ethical Review Committee for Research Animal, Faculty of Pharmacy, Chiang Mai University (Certificate of Ethical Clearance, No.: 01/2015 dated 15 September 2015). 


\subsection{Statistical analysis}

All the experiments were done in triplicate and analysis of variance (ANOVA) with a confident interval at 95\% $(p<0.05)$ was reported. The significance of the results was validated using SPSS (version 17.0).

\section{Results and discussion}

\subsection{Determination of glucan content}

All the selected ten yeast strains were subjected to total glucan extraction using yeast glucan assay kit. The yield, total glucan content, $\alpha$-glucan (AG) and $\beta$-glucan (BG) content of all the studied strains were tabulated (Table 1). The maximum extraction yield was obtained from the strain TISTR5623 $(3.72 \pm 0.31 \mathrm{~g} / \mathrm{L})$. Whereas, the maximum total glucan was recovered from HII31 $(49.21 \pm 3.96 \%)$ followed by TISTR5059 $(48.73 \pm 3.94 \%)$. Apparently, about $41.69 \pm 2.83 \%$ of BG has been extracted from HII31 with $7.52 \pm 0.93 \%$ of AG (Table 1).

FT-IR analysis is one of the appropriate methods used to study the biological samples. The determination of curve fitting and band area has been previously employed for the analysis of yeast cell wall (Galichet et al., 2001). All the extracts were subjected to FT-IR analysis and detected by the band area (\%) for major functional groups such as a polysaccharide $\left(925-1190 \mathrm{~cm}^{-1}\right)$, which represent the glucan content, protein $\left(1500-1700 \mathrm{~cm}^{-1}\right)$, and lipid (2800-3000 $\mathrm{cm}^{-1}$ ). Based on the percentage of band area of the different range, range ratio has been calculated. Even though strain TISTR5059 showed slightly higher polysaccharide content with respect to band area, the extract of HII31 strain showed the maximum ratio (2.1:1.5:1.0), which suggested that HII31 strain has comparatively high content of glucan (Table 2).

BG of a typical yeast cell consist of $\sim 30-45 \%$ of $\beta-1,3$ glucan and $\sim 5-10 \%$ of $\beta-1,6$ glucan (Soares \& Soares, 2012). In-depth, the band area for BG was separately analyzed, and the range ratio was calculated. The band area of different forms of $B G$ such as $\beta-1,3$ glucan, and $\beta-1,6$ glucan was tabulated (Table 3 ), and the maximum range ratio for BG was obtained in HII31, which suggested that the strain, HII31 was rich in BG than other strains tested. Furthermore, the strain HII31 has been selected in order to study the impact of different extraction method on yield and quality of BG, since HII31 showed a high content of BG in kit based extraction study. Moreover, quality and quantity of the BG depend on the extraction method (Liu et al., 2008).

HII31 cells were subjected to four different acid/base based extractions after autolysis, as detailed in materials and methods section and were denoted as E1-E4. The highest yield was recorded in E2 (72.68 $\pm 2.78 \%)$, followed by E1 $(68.50 \pm 2.66 \%)$, E3 (36.50

Table 1. Glucan content of selected S. cerevisiae strains.

\begin{tabular}{|c|c|c|c|c|c|}
\hline S. No. & S. cerevisiae strains & $\begin{array}{l}\text { Yield } \\
(\mathrm{g} / \mathrm{L})\end{array}$ & $\begin{array}{c}\text { Total-glucan } \\
(\%, \mathrm{w} / \mathrm{w})\end{array}$ & $\begin{array}{l}\text { a-glucan } \\
(\%, w / w) \\
\end{array}$ & $\begin{array}{l}\beta \text {-glucan } \\
(\%, w / w) \\
\end{array}$ \\
\hline 1 & HII31 & $3.53 \pm 0.26$ & $49.21 \pm 3.96^{\mathrm{a}}$ & $7.52 \pm 0.93$ & $41.69 \pm 2.83^{a \star}$ \\
\hline 2 & TISTR5003 & $3.30 \pm 0.28$ & $44.52 \pm 3.73$ & $8.21 \pm 0.96$ & $36.31 \pm 2.57$ \\
\hline 3 & TISTR5024 & $3.41 \pm 0.26$ & $46.34 \pm 3.82$ & $7.86 \pm 0.94$ & $38.48 \pm 2.67$ \\
\hline 4 & TISTR5051 & $3.66 \pm 0.30^{\mathrm{b}}$ & $47.45 \pm 3.87$ & $8.03 \pm 0.95$ & $39.42 \pm 2.72$ \\
\hline 5 & TISTR5059 & $3.52 \pm 0.28$ & $48.73 \pm 3.94^{\mathrm{b}}$ & $7.49 \pm 0.92$ & $41.24 \pm 2.83^{b}$ \\
\hline 6 & TISTR5191 & $3.23 \pm 0.25$ & $46.42 \pm 3.82$ & $7.84 \pm 0.94$ & $38.58 \pm 2.68$ \\
\hline 7 & TISTR5197 & $3.63 \pm 0.22^{c}$ & $45.91 \pm 3.80$ & $7.84 \pm 0.90$ & $38.07 \pm 2.65$ \\
\hline 8 & TISTR5278 & $3.38 \pm 0.27$ & $47.92 \pm 3.90$ & $7.85 \pm 0.89$ & $40.07 \pm 2.76$ \\
\hline 9 & TISTR5328 & $3.11 \pm 0.20$ & $46.25 \pm 3.81$ & $7.72 \pm 0.95$ & $38.53 \pm 2.68$ \\
\hline 10 & TISTR5623 & $3.72 \pm 0.31^{\mathrm{a}}$ & $47.93 \pm 3.91^{\mathrm{c}}$ & $7.33 \pm 0.92$ & $40.60 \pm 2.78^{c}$ \\
\hline
\end{tabular}

${ }^{\star}$ Significant value $(p<0.05) ;{ }^{\mathrm{a}-c}$ Represents the order of the highest values of representative parameters.

Table 2. Range ratios of polysaccharide, protein, and lipid content in the cell wall of selected S. cerevisiae strains.

\begin{tabular}{|c|c|c|c|c|c|}
\hline \multirow[b]{2}{*}{ S. No. } & \multirow[b]{2}{*}{ S. cerevisiae strains } & \multicolumn{3}{|c|}{ Band area (\%) } & \multirow[b]{2}{*}{$\begin{array}{l}\text { Range } \\
\text { ratio } \\
(1: 2: 3)\end{array}$} \\
\hline & & $\begin{array}{c}\text { Range } 1 \\
925-1,190 \mathrm{~cm}^{-1} \\
\text { (Polysaccharide) }(1)\end{array}$ & $\begin{array}{c}\text { Range } 2 \\
1,500-1,700 \mathrm{~cm}^{-1} \\
(\text { Protein })(2)\end{array}$ & $\begin{array}{c}\text { Range } 3 \\
2,800-3,000 \mathrm{~cm}^{-1} \\
\text { (Lipid) (3) }\end{array}$ & \\
\hline 1 & HII31 & 13.21 & 9.44 & 6.29 & $2.1: 1.5: 1.0$ \\
\hline 2 & TISTR5003 & 10.96 & 9.14 & 6.09 & $1.8: 1.5: 1.0$ \\
\hline 3 & TISTR5024 & 9.03 & 9.04 & 6.02 & $1.5: 1.5: 1.0$ \\
\hline 4 & TISTR5051 & 10.40 & 9.75 & 6.50 & $1.6: 1.5: 1.0$ \\
\hline 5 & TISTR5059 & 13.68 & 10.26 & 6.84 & $2.0: 1.5: 1.0$ \\
\hline 6 & TISTR5191 & 11.49 & 10.82 & 6.76 & $1.7: 1.6: 1.0$ \\
\hline 7 & TISTR5197 & 10.64 & 9.98 & 6.65 & 1.6:1.5:1.0 \\
\hline 8 & TISTR5278 & 10.84 & 8.43 & 6.02 & 1.8:1.4:1.0 \\
\hline 9 & TISTR5328 & 11.75 & 7.84 & 6.53 & 1.8:1.2:1.0 \\
\hline 10 & TISTR5623 & 11.95 & 10.62 & 6.64 & $1.8: 1.6: 1.0$ \\
\hline
\end{tabular}


$\pm 2.56 \%)$, and E4 $(22.65 \pm 1.59 \%)$ (Figure 1a). The content of $B G$ and $A G$ in the preparations also suggested that the E2 recovered relatively higher BG $(93.42 \pm 3.57 \%)$ from HII31 cells than other extraction methods (Figure 1b).

All the extracts were subjected to FT-IR analysis and the band area analysis was done using Origin Pro 8.0 software. The calculated range ratio (polysaccharide: protein: lipid), suggested that E2 yielded high ratio (4.5:1.0:1.1) with a high content of polysaccharide (68.18\%). Followed by E1 recorded for $66.67 \%$ of polysaccharide content in the extract (Table 4). The ratio of $\beta-1,3$ glucan, and $\beta-1,6$ glucan were also considered, and it was observed that high content of $\beta-1,3$ glucan was present in all the preparations, especially E2 extracts which contain about 12.57 fold higher $\beta-1,3$ glucan than $\beta-1,6$ glucan (Table 5 ).

\subsection{In vivo immunomodulatory effect}

BG can modify the immune regulation of a host. The source and forms of $\mathrm{BG}$ can also influence it. Both in vitro and in vivo studies suggested that $B G$ of fungi and yeast have potent immune modulating properties (Volman et al., 2008). The ultimate objective of this study is to explore the extracted BG as an adjuvant for the treatment of colitis in human. Thus, we have selected the representative cytokines, which are known to be involved in colitis and other gastroenteritis related diseases. In the present study, the extract obtained from E2 was selected and subjected to immunomodulatory effect study using mice.

As detailed earlier, animals were separated into four different groups and treated with different concentration of air-dried BG (100, 150, $200 \mathrm{mg}$ of BG/kg of body weight). After the study period, animals were investigated for the level of selected pro-inflammatory (IL-6, IL-17, and IFN- $\gamma$ ) and anti-inflammatory cytokines (IL-10, and TGF- $\beta$ ).

All tested cytokines expression were elevated upon E2 extract intervention (Figure 2). The expression of IL-6 was not significantly affected by the different concentration of the extract,
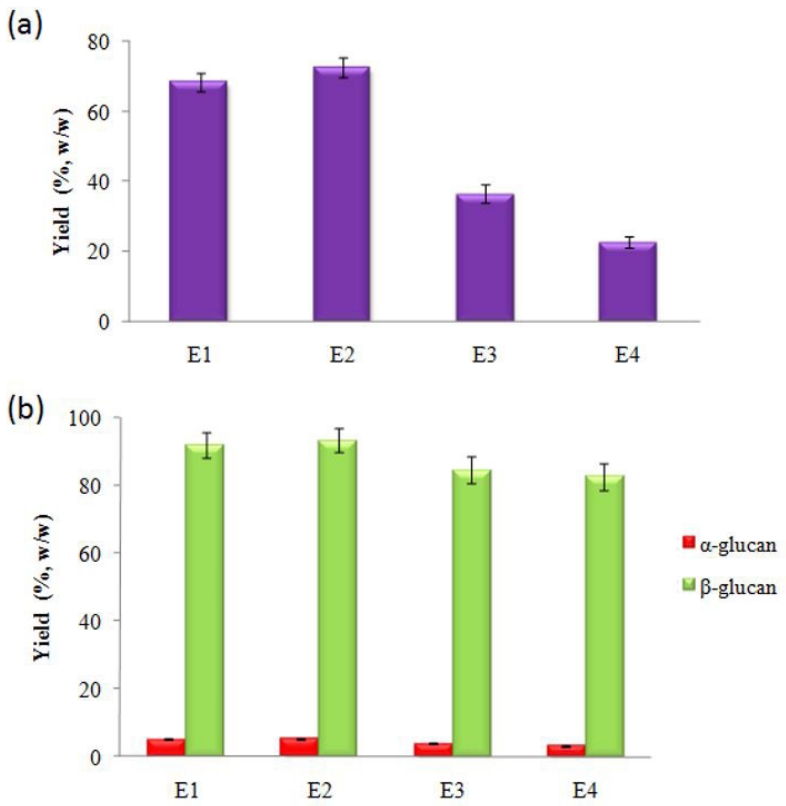

Figure 1. Influence of different extraction methods on total yield (a), and the percentage yield of BG and AG from HII31 (b).

Table 3. The band area and ratio of different forms of $\beta$-glucan from selected S. cerevisiae strains.

\begin{tabular}{|c|c|c|c|c|c|}
\hline \multirow[b]{2}{*}{ S. No } & \multirow[b]{2}{*}{ S. cerevisiae strains } & \multicolumn{3}{|c|}{ Band area (\%) } & \multirow{2}{*}{$\begin{array}{c}\text { Range } \\
\text { ratio } \\
(1: 2: 3)\end{array}$} \\
\hline & & $\beta$-1,3-glucan (1) & $\beta$-1,4-glucan (2) & $\beta$-1,6-glucan (3) & \\
\hline 1 & HII31 & 48.70 & 15.22 & 27.40 & $3.2: 1.0: 1.8$ \\
\hline 3 & TISTR5024 & 33.06 & 12.24 & 19.59 & $2.7: 1.0: 1.6$ \\
\hline 4 & TISTR5051 & 34.61 & 12.82 & 16.67 & $2.7: 1.0: 1.3$ \\
\hline 5 & TISTR5059 & 52.47 & 17.49 & 31.48 & $3.0: 1.0: 1.8$ \\
\hline 7 & TISTR5197 & 48.64 & 15.69 & 23.54 & $3.1: 1.0: 1.5$ \\
\hline 8 & TISTR5278 & 45.09 & 15.03 & 22.55 & $3.0: 1.0: 1.5$ \\
\hline 9 & TISTR5328 & 38.95 & 13.43 & 30.89 & $2.9: 1.0: 2.3$ \\
\hline 10 & TISTR5623 & 38.82 & 16.17 & 24.26 & $2.4: 1.0: 1.5$ \\
\hline
\end{tabular}

Note: $\beta$-1,3-glucan spectrum: $\sim 1,042 \mathrm{~cm}^{-1}, \sim 1,108 \mathrm{~cm}^{-1}, \sim 1,135 \mathrm{~cm}^{-1} ; \beta$-1,4-glucan spectrum: $\sim 1,025 \mathrm{~cm}^{-1} ; \beta$-1,6-glucan spectrum: $\sim 998 \mathrm{~cm}^{-1}$.

Table 4. Range ratios of polysaccharide, protein, and lipid content in the cell wall of HII31 recovered by a different method.

\begin{tabular}{|c|c|c|c|c|c|c|}
\hline \multirow[b]{2}{*}{ S. No. } & \multirow[b]{2}{*}{ Fractions } & \multicolumn{3}{|c|}{ Band area (\%) } & \multirow[b]{2}{*}{$\begin{array}{l}\text { Range } \\
\text { ratio } \\
(1: 2: 3)\end{array}$} & \multirow[b]{2}{*}{$\begin{array}{c}\text { Content (\%) } \\
\text { of polysaccharide }\end{array}$} \\
\hline & & $\begin{array}{c}\text { Range } 1 \\
925-1,190 \mathrm{~cm}^{-1} \\
\text { (Polysaccharide) }\end{array}$ & $\begin{array}{c}\text { Range } 2 \\
1,500-1,700 \mathrm{~cm}^{-1} \\
\text { (Protein) }\end{array}$ & $\begin{array}{c}\text { Range } 3 \\
2,800-3,000 \mathrm{~cm}^{-1} \\
\text { (Lipid) }\end{array}$ & & \\
\hline 1 & E1 & 18.98 & 4.52 & 4.97 & $4.2: 1.0: 1.1$ & 66.67 \\
\hline 2 & E2 & 18.36 & 4.08 & 4.49 & $4.5: 1.0: 1.1$ & 68.18 \\
\hline 3 & E3 & 16.18 & 4.76 & 5.24 & 3.4:1.0:1.1 & 61.82 \\
\hline 4 & E4 & 15.40 & 5.50 & 4.43 & 2.8:1.0:1.0 & 58.33 \\
\hline
\end{tabular}



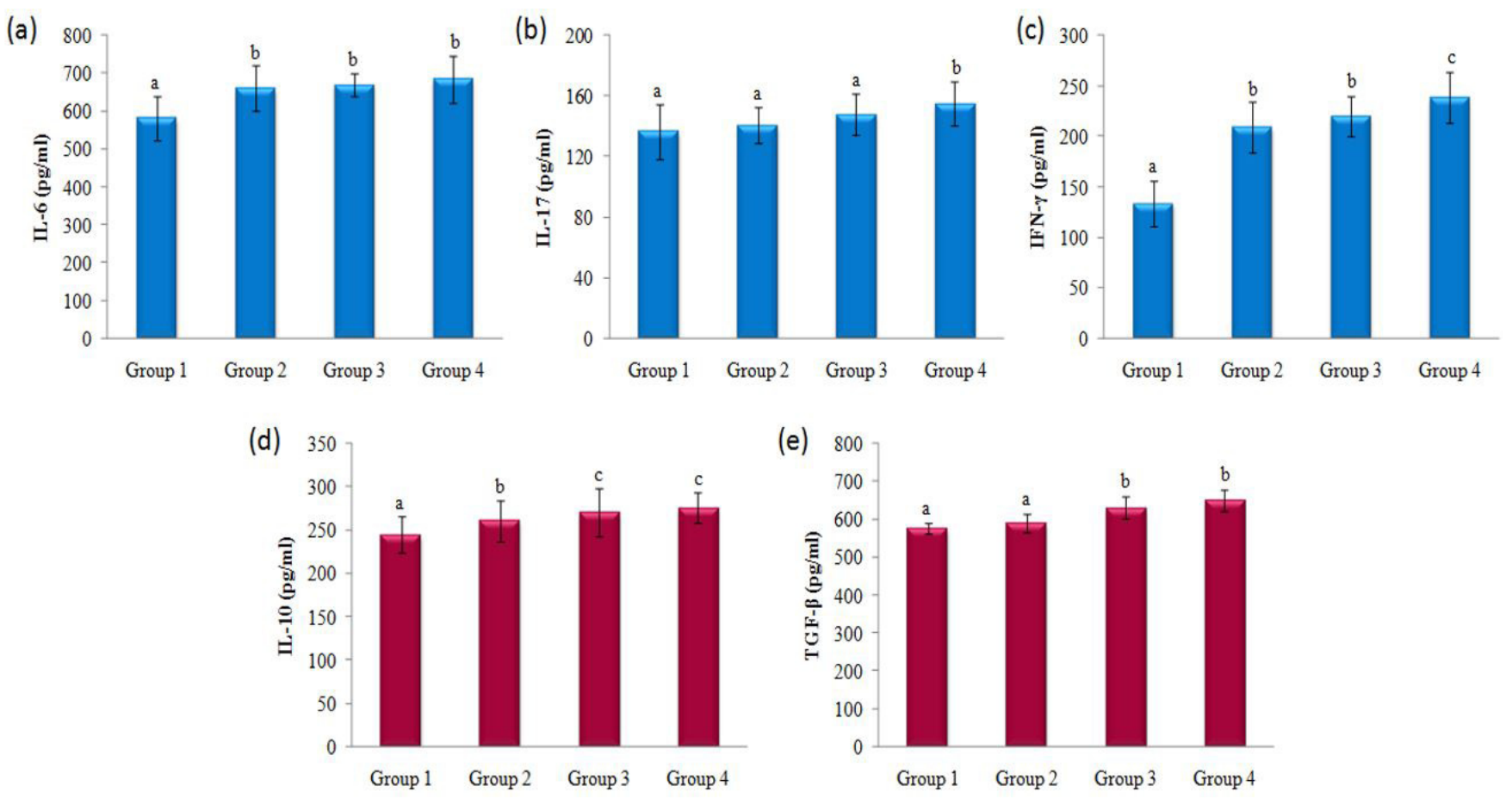

Figure 2. The expression profile of selected cytokines such as IL-6 (a), IL-17(b), IFN- $\alpha$ (c), IL-10 (d), and TGF- $\beta$ (e) upon the different concentration of BG intervention. Group 1: control; Group 2-4: 50, 100, and $150 \mathrm{mg}$ per Kg of body weight of BG supplementation, respectively. The alphabets (a-c) indicates the significant $(p>0.005)$ difference among the groups.

Table 5. The ratio of $\beta$-1,3- and $\beta$-1,6-glucan extracted from HII31.

\begin{tabular}{ccccc}
\hline \multirow{2}{*}{ S. No. } & \multirow{2}{*}{ Strains } & \multicolumn{2}{c}{ Band area $(\%)$} & \multirow{2}{*}{$\begin{array}{c}\text {-glucan ratio } \\
(\beta-1,3: \beta-1,6)\end{array}$} \\
\cline { 3 - 4 } & & $\beta$-1,3-glucan & $\beta$-1,6-glucan & 7.12 \\
\hline 1 & E1 & 45.85 & 6.44 & 12.57 \\
2 & E2 & 78.19 & 6.22 & 5.00 \\
3 & E3 & 32.70 & 6.54 & 2.19 \\
4 & E4 & 15.59 & 7.12 & \\
\hline
\end{tabular}

Note: $\beta$-1,3-glucan spectrum: $\sim 1,042 \mathrm{~cm}^{-1}, \sim 1,108 \mathrm{~cm}^{-1}, \sim 1,135 \mathrm{~cm}^{-1} ; \beta$-1,6-glucan spectrum: $\sim 998 \mathrm{~cm}^{-1}$.

whereas the significant level of increased expression of IL-6 was observed between control and treated samples.

The low doses (100 and $150 \mathrm{mg}$ of BG/kg of body weight) of extract, does not disturb the level of IL-17, but high concentration accelerated the level of IL-17 compared to control. Interestingly, IFN- $\gamma$ expression was positively regulated in a dose-depended manner. These observations suggested that extracted BG intervention induces the expression of selected inflammatory cytokines significantly in mice (Figure 2). The level of representative anti-inflammatory cytokines was assessed upon extract supplementation. The expression of IL-10 and TGF- $\beta$ was upregulated in BG supplemented groups with respective dose. The results suggested that low dose of BG was enough to induce the expression of IL-10 significantly, whereas relatively high dose was required to alter the TGF- $\beta$ expression (Figure 2).
It is known that yeast BG can induce the expression of TGF- $\beta$ (Olson et al., 1996; Tzianabos, 2000) TNF- $\alpha$, IL-6, IL-10 (Engstad et al., 2002). TGF- $\beta$, and inhibitory cytokine, are involved in the regulation of defense and inflammatory responses of the host, and the possible pro-inflammatory character was observed among ulcerative colitis patients (Roda et al., 2011). IL-10, a typical anti-inflammatory cytokine, which are released mostly by T cells, B cells and monocytes that suppress the IL-6, and IFN- $\gamma$ expressions (Rogler \& Andus, 1998; Rennick \& Fort, 2000). The cytokines are involved in many regulatory functions during disease conditions like colitis, tumor development, and inflammatory bowel diseases (Sanchez-Muñoz et al., 2008; Roda et al., 2011; Müzes et al., 2012). The current study, therefore, suggests that the intervention of BG extracted from the yeast strain HII31 could alter the expression of selected pro and anti-inflammatory cytokines in mice.

\section{Conclusion}

The yeast strain with a high content of BG was screened and characterized. The current study also compared the methods for the extraction of BG from selected yeast strain and found out that the combination of a strong base $(\mathrm{NaOH})$ and weak acid $\left(\mathrm{CH}_{3} \mathrm{COOH}\right)$ extraction could yield high-quality BG. The composition of extracts has been achieved through FT-IR analysis. The immunomodulatory effect of best quality BG, with respect to polysaccharide content, has been assessed, and the results revealed that isolated $B G$ could alter the expression of selected cytokines appropriately. 


\section{Acknowledgements}

The authors gratefully acknowledge the CMU research grant, and Faculty of Pharmacy and Chiang Mai University, Chiang Mai, Thailand.

\section{References}

Ahmad, A., Anjum, F. M., Zahoor, T., Nawaz, H., \& Dilshad, S. M. R. (2012). Beta glucan: a valuable functional ingredient in foods. Critical Reviews in Food Science and Nutrition, 52(3), 201-212. http://dx.doi. org/10.1080/10408398.2010.499806. PMid:22214441.

Bacic, A., Fincher, G. B., \& Stone, B. A., editors (2009). Chemistry, biochemistry, and biology of 1-3 beta glucans and related polysaccharides. Burlington: Academic Press.

Boonraeng, S., Foo-Trakul, P., Kanlayakrit, W., Chetanachitra, C., \& Kasetsart, J. (2000). Effects of chemical, biochemical and physical treatments on the kinetics and on the role of some endogenous enzymes action of baker's yeast lysis for food-grade yeast extract production. Natural Science, 34, 270-278.

Brown, G. D., \& Gordon, S. (2003). Fungal beta-glucans and mammalian immunity. Immunity, 19(3), 311-315. http://dx.doi.org/10.1016/ S1074-7613(03)00233-4. PMid:14499107.

Brown, G. D., \& Gordon, S. (2005). Immune recognition of fungal $\beta \bigotimes$ glucans. Cellular Microbiology, 7(4), 471-479. http://dx.doi. org/10.1111/j.1462-5822.2005.00505.x. PMid:15760447.

Brown, G. D., Herre, J., Williams, D. L., Willment, J. A., Marshall, A. S., \& Gordon, S. (2003). Dectin-1 mediates the biological effects of $\beta$-glucans. The Journal of Experimental Medicine, 197(9), 1119-1124. http://dx.doi.org/10.1084/jem.20021890. PMid:12719478.

Burkus, Z., \& Temelli, F. (2000). Stabilization of emulsions and foams using barley $\beta$-glucan. Food Research International, 33(1), 27-33. http://dx.doi.org/10.1016/S0963-9969(00)00020-X.

Chan, G. C., Chan, W. K., \& Sze, D. M. (2009). The effects of betaglucan on human immune and cancer cells. Journal of Hematology \& Oncology, 2(25), 1-11. http://dx.doi.org/10.1186/1756-8722-2-25. PMid:19515245.

Dawkins, N. L., \& Nnanna, I. A. (1995). Studies on oat gum $[(1 \rightarrow 3$, $1 \rightarrow 4)-\beta$-D-glucan]: composition, molecular weight estimation and rheological properties. Food Hydrocolloids, 9(1), 1-7. http://dx.doi. org/10.1016/S0268-005X(09)80188-4.

Dongowski, G., Huth, M., Gebhardt, E., \& Flamme, W. (2002). Dietary fiber-rich barley products beneficially affect the intestinal tract of rats. The Journal of Nutrition, 132(12), 3704-3714. PMid:12468611.

Engstad, C. S., Engstad, R. E., Olsen, J. O., \& Osterud, B. (2002). The effect of soluble $\beta$-1, 3-glucan and lipopolysaccharide on cytokine production and coagulation activation in whole blood. International Immunopharmacology, 2(11), 1585-1597. http://dx.doi.org/10.1016/ S1567-5769(02)00134-0. PMid:12433059.

Ferrer, P. (2006). Revisiting the Cellulosimicrobium cellulans yeast-lytic $\beta$-1, 3-glucanases toolbox: a review. Microbial Cell Factories, 5(1), 10. http://dx.doi.org/10.1186/1475-2859-5-10. PMid:16545129.

Galichet, A., Sockalingum, G. D., Belarbi, A., \& Manfait, M. (2001). FTIR spectroscopic analysis of Saccharomyces cerevisiae cell walls: study of an anomalous strain exhibiting a pink-colored cell phenotype. FEMS Microbiology Letters, 197(2), 179-186. http:// dx.doi.org/10.1111/j.1574-6968.2001.tb10601.x. PMid:11313132.

Hallfrisch, J., Scholfield, D. J., \& Behall, K. M. (2003). Physiological responses of men and women to barley and oat extracts (Nu-trimX). II. Comparison of glucose and insulin responses. Cereal Chemistry, 80(1), 80-83. http://dx.doi.org/10.1094/CCHEM.2003.80.1.80.
Hlebowicz, J., Darwiche, G., Björgell, O., \& Almér, L. O. (2008). Effect of muesli with $4 \mathrm{~g}$ oat $\beta$-glucan on postprandial blood glucose, gastric emptying and satiety in healthy subjects: a randomized crossover trial. Journal of the American College of Nutrition, 27(4), 470-475. http://dx.doi.org/10.1080/07315724.2008.10719727. PMid:18978166.

Hunter, K. W. Jr., Gault, R. A., \& Berner, M. D. (2002). Preparation of microparticulate $\beta \bigotimes$ glucan from Saccharomyces cerevisiae for use in immune potentiation. Letters in Applied Microbiology, 35(4), 267-271. http://dx.doi.org/10.1046/j.1472-765X.2002.01201.x. PMid:12358685.

Javmen, A., Grigiskis, S., \& Gliebute, R. (2012). $\beta$-glucan extraction from Saccharomyces cerevisiae yeast using Actinomyces rutgersensis 88 yeast lyzing enzymatic complex. Biologija (Vilnius, Lithuania), 58(2), 51-59. http://dx.doi.org/10.6001/biologija.v58i2.2486.

Kesika, P., Prasanth, M. I., \& Balamurugan, K. (2015). Modulation of Caenorhabditis elegans immune response and modification of Shigella endotoxin upon interaction. Journal of Basic Microbiology, 55(4), 432-450. http://dx.doi.org/10.1002/jobm.201400511. PMid:25384571.

Lee, J. N., Lee, D. Y., Ji, I. H., Kim, G. E., Kim, H. N., Sohn, J., Kim, S., \& Kim, C. W. (2001). Purification of soluble $\beta$-glucan with immune-enhancing activity from the cell wall of yeast. Bioscience, Biotechnology, and Biochemistry, 65(4), 837-841. http://dx.doi. org/10.1271/bbb.65.837. PMid:11388461.

Liu, X. Y., Wang, Q., Cui, S. W., \& Liu, H. Z. (2008). A new isolation method of $\beta$-D-glucans from spent yeast Saccharomyces cerevisiae. Food Hydrocolloids, 22(2), 239-247. http://dx.doi.org/10.1016/j. foodhyd.2006.11.008.

Müzes, G., Molnár, B., Tulassay, Z., \& Sipos, F. (2012). Changes of the cytokine profile in inflammatory bowel diseases. World Journal of Gastroenterology: WJG, 18(41), 5848-5861. http://dx.doi.org/10.3748/ wjg.v18.i41.5848. PMid:23139600.

Olson, E. J., Standing, J. E., Griego-Harper, N., Hoffman, O. A., \& Limper, A. H. (1996). Fungal beta-glucan interacts with vitronectin and stimulates tumor necrosis factor alpha release from macrophages. Infection and Immunity, 64(9), 3548-3554. PMid:8751898.

Pelizon, A. C., Kaneno, R., Soares, A. M. V. C., Meira, D. A., \& Sartori, A. (2005). Immunomodulatory activities associated with $\beta$-glucan derived from Saccharomyces cerevisiae. Physiological Research, 54(5), 557-564. PMid:16238470.

Rennick, D. M., \& Fort, M. M. (2000). Lessons from genetically engineered animal models. XII. IL-10-deficient (IL-10 (-/-) mice and intestinal inflammation. American Journal of Physiology. Gastrointestinal and Liver Physiology, 278(6), G829-G833. PMid:10859210.

Roda, G., Marocchi, M., Sartini, A., \& Roda, E. (2011). Cytokine networks in ulcerative colitis. Ulcers, 2011, 1-5. http://dx.doi. org/10.1155/2011/391787.

Rogler, G., \& Andus, T. (1998). Cytokines in inflammatory bowel disease. World Journal of Surgery, 22(4), 382-389. http://dx.doi. org/10.1007/s002689900401. PMid:9523521.

Sánchez-Madrigal, M. Á., Neder-Suárez, D., Quintero-Ramos, A., RuizGutiérrez, M. G., Meléndez-Pizarro, C. O., Piñón-Castillo, H. A., Galicia-García, T., \& Ramírez-Wong, B. (2015). Physicochemical properties of frozen tortillas from nixtamalized maize flours enriched with $\beta$-glucans. Food Science and Technology, 35(3), 552-560. http:// dx.doi.org/10.1590/1678-457X.6715.

Sanchez-Muñoz, F., Dominguez-Lopez, A., \& Yamamoto-Furusho, J. K. (2008). Role of cytokines in inflammatory bowel disease. World Journal of Gastroenterology, 14(27), 4280-4288. http://dx.doi. org/10.3748/wjg.14.4280. PMid:18666314.

Shokri, H., Asadi, F., \& Khosravi, A. R. (2008). Isolation of $\beta$-glucan from the cell wall of Saccharomyces cerevisiae. Natural Product Research, 
22(5), 414-421. http://dx.doi.org/10.1080/14786410701591622. PMid:18404561.

Sivamaruthi, B. S., Prasanth, M. I., \& Balamurugan, K. (2015). Alterations in Caenorhabditis elegans and Cronobacter sakazakii lipopolysaccharide during interaction. Archives of Microbiology, 197(2), 327-337. http:// dx.doi.org/10.1007/s00203-014-1064-1. PMid:25416126.

Soares, E. V., \& Soares, H. M. (2012). Bioremediation of industrial effluents containing heavy metals using brewing cells of Saccharomyces cerevisiae as a green technology: a review. Environmental Science and Pollution Research International, 19(4), 1066-1083. http://dx.doi. org/10.1007/s11356-011-0671-5. PMid:22139299.

Tungland, B. C. (2003). Fructooligosaccharides and other fructans: structures and occurrence, production, regulatory aspects, food applications, and nutritional health significance. In G. Eggleston \& G. L. Cote (Eds.), Oligosaccharides in food and agriculture (ACS Symposium Series, Vol. 849, pp. 135-152). Washington: American Chemical Society. http://dx.doi.org/10.1021/bk-2003-0849.ch011.
Tzianabos, A. O. (2000). Polysaccharide immunomodulators as therapeutic agents: structural aspects and biologic function. Clinical Microbiology Reviews, 13(4), 523-533. http://dx.doi.org/10.1128/ CMR.13.4.523-533.2000. PMid:11023954.

Vetvicka, V. (2011). Glucan-immunostimulant, adjuvant, potential drug. World Journal of Clinical Oncology, 2(2), 115-119. http:// dx.doi.org/10.5306/wjco.v2.i2.115. PMid:21603320.

Volman, J. J., Ramakers, J. D., \& Plat, J. (2008). Dietary modulation of immune function by $\beta$-glucans. Physiology \& Behavior, 94(2), 276-284. http://dx.doi.org/10.1016/j.physbeh.2007.11.045. PMid:18222501.

Wang, J., Rosell, C. M., \& Barber, C. B. (2002). Effect of the addition of different fibres on wheat dough performance and bread quality. Food Chemistry, 79(2), 221-226. http://dx.doi.org/10.1016/S03088146(02)00135-8.

Wenger, M. D., DePhillips, P., \& Bracewell, D. G. (2008). A microscale yeast cell disruption technique for integrated process development strategies. Biotechnology Progress, 24(3), 606-614. http://dx.doi. org/10.1021/bp070359s. PMid:18410155. 